\title{
プレローディド・プレストレスト補強土の 現場計測結果と設計法・施工法の提案
}

\author{
東京大学工学部 内村太郎・龍岡文夫 \\ 東京大学生産技術研究所 古関潤一 \\ 鉄道総合技術研究所 舘山 勝 \\ 九州旅客鉄道株式会社 古賀徹志
}

\begin{abstract}
プレローディド・プレストレスト（P L ・P S ）補強土エ法は、プレロードとプレストレスによって 補強盛土の剛性を飛躍的に高め、より大きな荷重を受ける構造物（橋台、橋脚、重要構造物の基礎な ど）にも応用できるようにする工法である。この工法の初の実施工例として、鉄道橋の橋脚が建設さ れた。その長期計測と列車通過時の計測結果から、P L ・ P S 補強盛土の長期耐久性・短期の変形特 性を検討した。その結果、P L ・ P S 橋脚は、死荷重によるクリープ圧縮速度、列車荷重の繰返し載 荷による残留圧縮速度、補強材の伸びひずみ速度は、いづれも実用上十分小さかった。また、列車通 過時の一時的な圧縮量も、十分小さかった。さらに、P L ・ P S 補強盛土の剛性を長期にわたって確 実に維持する方法と、施工性の改善の観点から、設計・施工上工夫すべき点を考察した。
\end{abstract}

Full-scale Behaviour of Prototype Preloaded and Prestressed Geosynthetic Reinforced Soil Structure and Some Proposals to its Design and Construction Method.

T.Uchimura and F. Tatsuoka : Department of Civil Engineering, University of Tokyo

J.Koseki : Institute of Industrial Science, University of Tokyo

M.Tateyama : Railway Technical Research Institute of Japan Railways Group

T.Koga : Kyushu Railway Company

The preloaded and prestressed (PLPS) reinforced soil method aims at substantially increasing the stiffness of a geosynthetic-reinforced soil embankment by vertical preloading and prestressing. The first prototype PLPS reinforced soil pier for a railway was constructed, and preloaded and prestressed, which has been opened to service for more than 1 year. Long-term measurements for more than 2 years are described. The PLPS pier showed very small amount of instantaneous and creep compression by dead load and live train load. In addition, some new design and construction methods are proposed which can keep high stiffness for a long time and can improve its constructibility. 


\section{プレローディド・プレストレスト補強土の}

\section{現場計測結果と設計法・施工法の提案}

\author{
東京大学工学部 内村太郎・龍岡文夫 \\ 鉄道総合技術研究所 舘山 勝
}

\begin{abstract}
東京大学生産技術研究所 古関潤一
九州旅客鉄道株式会社 古賀徹志
\end{abstract}

\section{1.工法の概要とメカニズム}

プレローディド・プレストレスト（P L ・P S ）補強土エ法は、プレロードとプレストレスによっ て補強盛土の剛性を飛躍的に高め、より大きな荷重を受ける構造物（橋台、橋脚、重要構造物の基礎 など）にも応用できるようにする工法である。従来の鉄筋コンクリート（R C ）構造に比べ、杭基礎 を省略できたり現場発生土を利用できる場合にはかなり安価になる。また土は延性的なので、基礎地 盤の変形にも致命的な破壊をせず柔軟に 追従する"。

図 1 にP L · P S 補強土工法の概念図 を示す。補強盛土に 4 本以上のタイロッ ド（ P C 鋼棒など）を鉛直に挿入して、 下端は盛土底部の反力板（RCブロック など）に締結しておく。タイロッド上端 に、上部反力板を反力にしてジャッキを 設置し、タイロッドを十分強い力で引張 ることで、盛土を鉛直方向にプレロード 寸る。盛土はジオテキスタイルで補強さ れているので、高い鉛直プレロードに耐

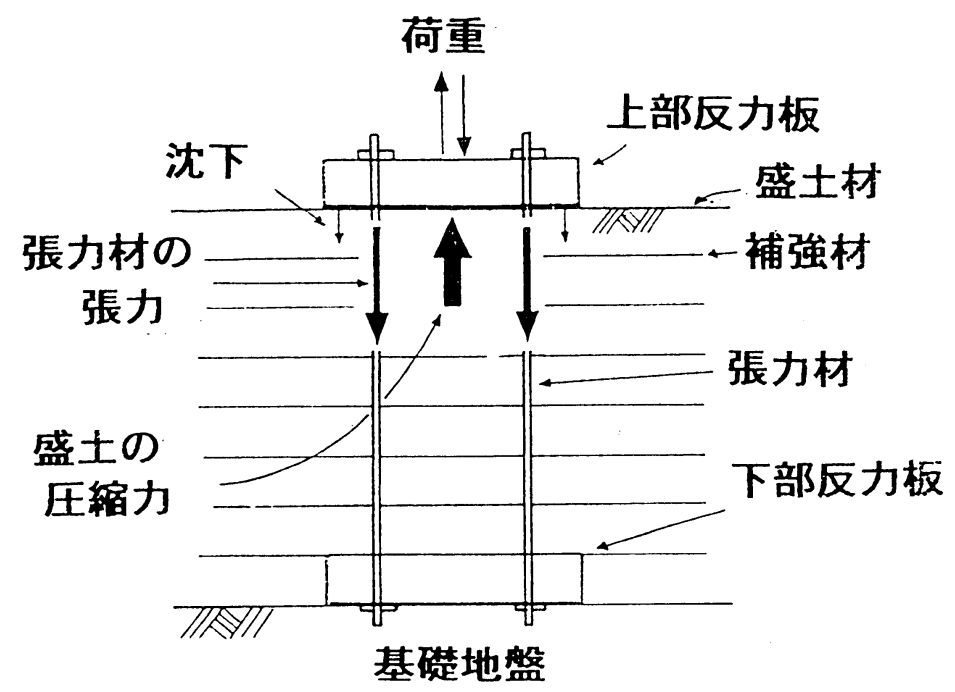
える強度が十分にある。次に張力を緩め てプレロードを半分程度除荷する。最後

図 1 プレローディド・プレストレスト補強盛土の概念図 にタイロッドと反力板をナットなどの締結具で固定し、ジャッキを外ず。タイロッドには引張、盛士 には圧絎のプレストレスが残る。

補強盛士の鉛㨁荷重に対す万剛性が间上寸るメカニズムは、次の4つである。

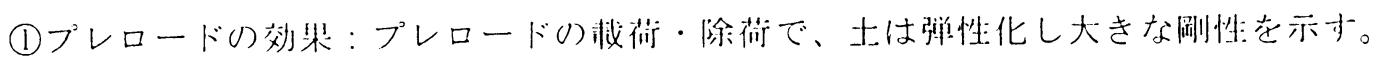

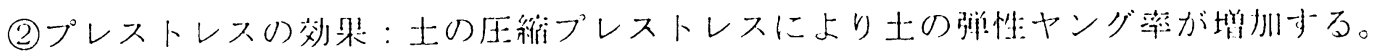

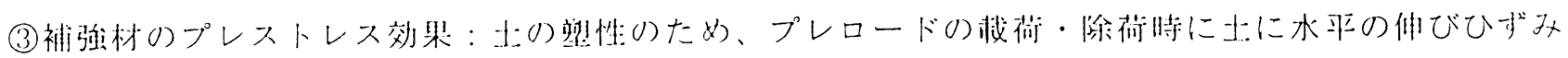

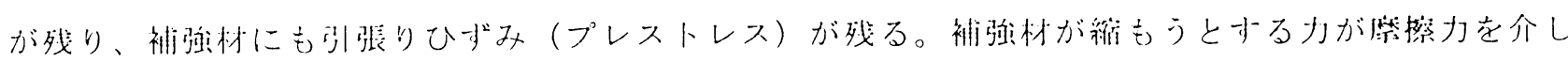

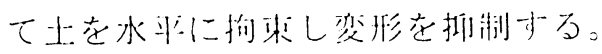

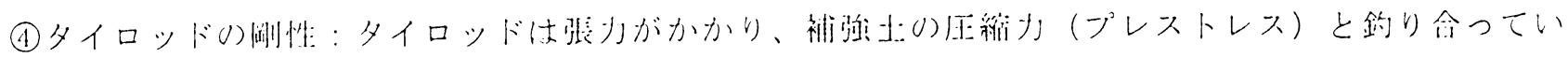

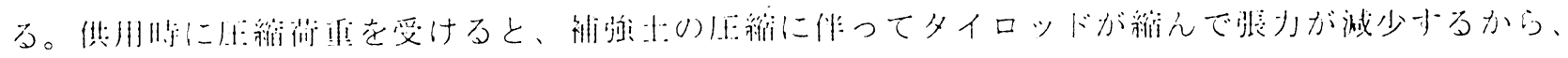

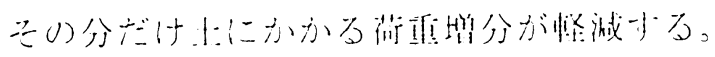




\section{2.実施工のP L・P S 補強土橋台の計測}

1996年夏に、J R九州篠栗線馬出橋梁（福岡市：図 2 a ）で、初の実施工のP L・P S 補强土橋脚 として橋脚 P 1 が建設された（図 2 b ) ${ }^{2}$ ) 3 )。盛土材は粒度調整砕石、補強材はポリマーグリッドであ り、16.5 m の桁を 2 連支持している。上部反力板として R C 小橋台（厚さ $80 \mathrm{~cm}$ ）を兼用し、タイロッ ドには直径 $35 \mathrm{~mm}$ のP C 鋼棒を 4 本用いた。基礎地盤は厚さ $11 \mathrm{~m}$ の軟弱粘土層だったため、セメン ト混合で改良した。さらに、地表面から梁さ $1 \mathrm{~m}$ までは、地盤改良杭を密に打設して、これを下部反 力板として代用した。タイロッドの下端は、改良杭に約 $4 \mathrm{~m}$ 挿入し定着した。補強土部分は、4 辺に レキの入った土のうを積み上げてグリッドで巻き込みながら構筑した。グリッドは、向かい合う2 壁 面ごとに $30 \mathrm{~cm}$ 間隔で敷設したため、全体で $15 \mathrm{~cm}$ となっている。盛土構築後、4壁面に厚さ $30 \mathrm{~cm} の$ $\mathrm{RC}$ 剛壁面を打設した。橋脚の設計桁荷重は $197 \mathrm{kN}=20.1 \mathrm{tf}$ 、設計列車荷重は衝撃荷重を含めて $1330 \mathrm{kN}$ =136tf である。仮設構造物として、5 年間程度使用する予定である。

一方、この橋梁の橋台A２（図２ｃ）は、剛な壁面工を持つ補強土擁壁であるが、プレロード・プ レストレスはかけていない。R C 壁面工は前面にだけ施工され、側面は植生した法面である。

図 3 は、橋脚の、油圧ジャッキで加えたプレロード荷重（タイロッドの張力に等しい）と鈶直圧樎 量との関倸である。初日はプレロード荷重を $196 \mathrm{kN}$ ずつ增やしながら、30分または60分ずつクリープ

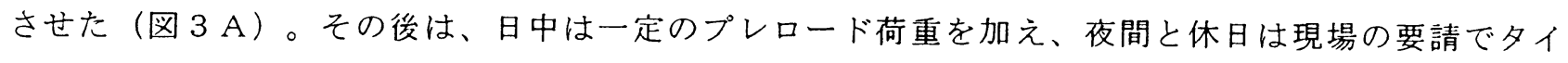
ロッドを反力板に締結して放置した（プレロード載荷時間は、合計で正味約72時間である）。途中で 大振幅の繰返し荷重を数回かけた。最終的に $2350 \mathrm{kN}=240 \mathrm{tf}$ のプレロードをかけ、13日目にタイロ ッドの張力を $950 \mathrm{kN}=97 \mathrm{tf}$ に除荷して、タイロッドと反力板とを固定した。プレロード時の盛土の 鉛直圧縮量は最大 $8 \mathrm{~mm}$ であり、また $1080 \sim 2350 \mathrm{kN}$ で除荷・再載荷した時の弹性的変形は $0.5 \mathrm{~mm}$ (図 3 B ）で、非常に测性が高かった。以降、プレストレスされた状態で約 2 年問計測を続けた（図 3 C）。

図 4 は、プレロード後、約 2 年問のタイロッド張力（プレストレス）、P L P P S 橋脚の圧縮量、 P L ・ P S をかけてない補強土橋台の圧縮量である。それぞれ、およそ 1 年周期のわずかな変動を含 えでいるが、これは温度変化による盛土変形か、もしくは計測装置への㵆度の影響と思われる。外気 温と橋脚内部の各点の地中温度を、熱電対で計测した（図５）。地中温度の日变化は、外気温よりは るかに小さい。しかし、1 年周期の変化を見ると、盛土内部の温度はほぼ一様で外気温に等しいと言 える。その温度が極小・極大となる時と、タイロッド張力や盛土の压縮舁が極小・極大となる洔とが 一致している(四中○印）。このことから、上述の年变化は温度による变動だと判断した。

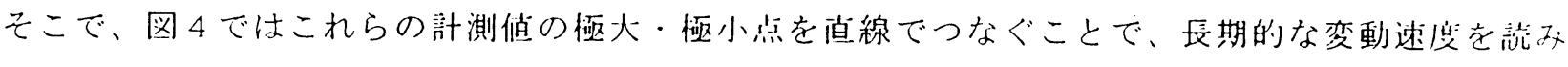

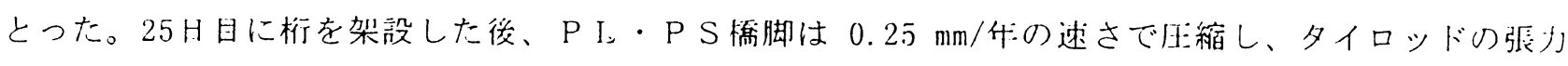
は $51 \mathrm{kN} /$ 年で減少している。300日日付近で供用開始し、それ以降 $392 \mathrm{kN}(40 \mathrm{tf})$ 程度の列杰街重が 1 日 に125回以上かかるようになったが、盛士の压縮速度、タイロッド张力の城少述度に㩆著な変化は见 られない。盛上の圧箱速度とタイロッド辳力の減少速度の比をとると、204k.V/mm となり、ニれが夕イ

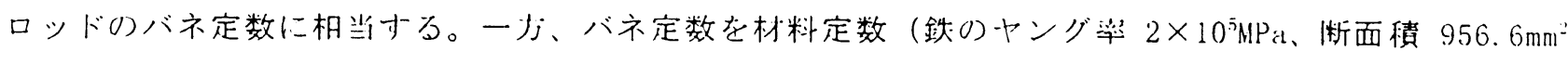

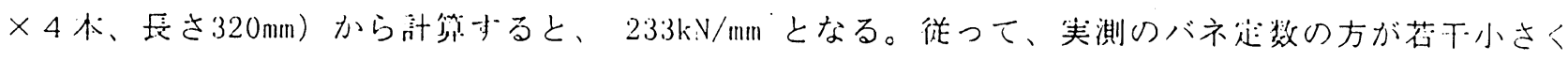
なっているが、理山として、タイロッド上下端の定着部にわ才゙かな緩みがあり得ることが法えられる。 

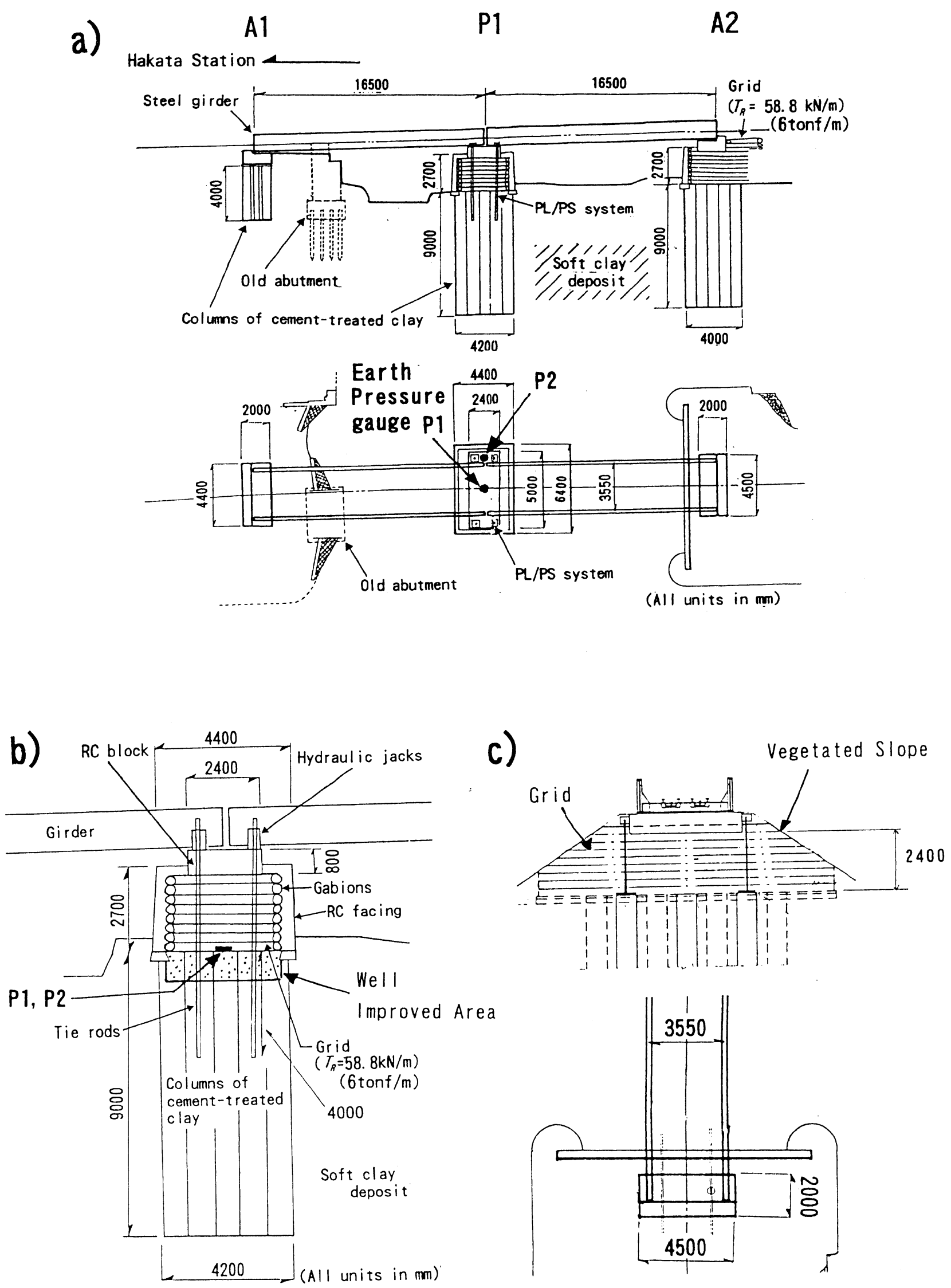

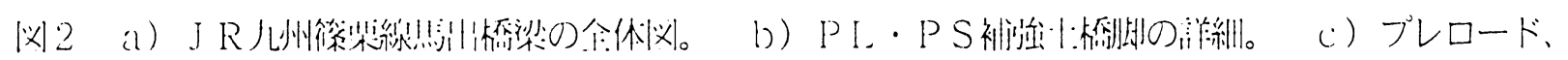

プレストレスをかけない初离小橋吉 


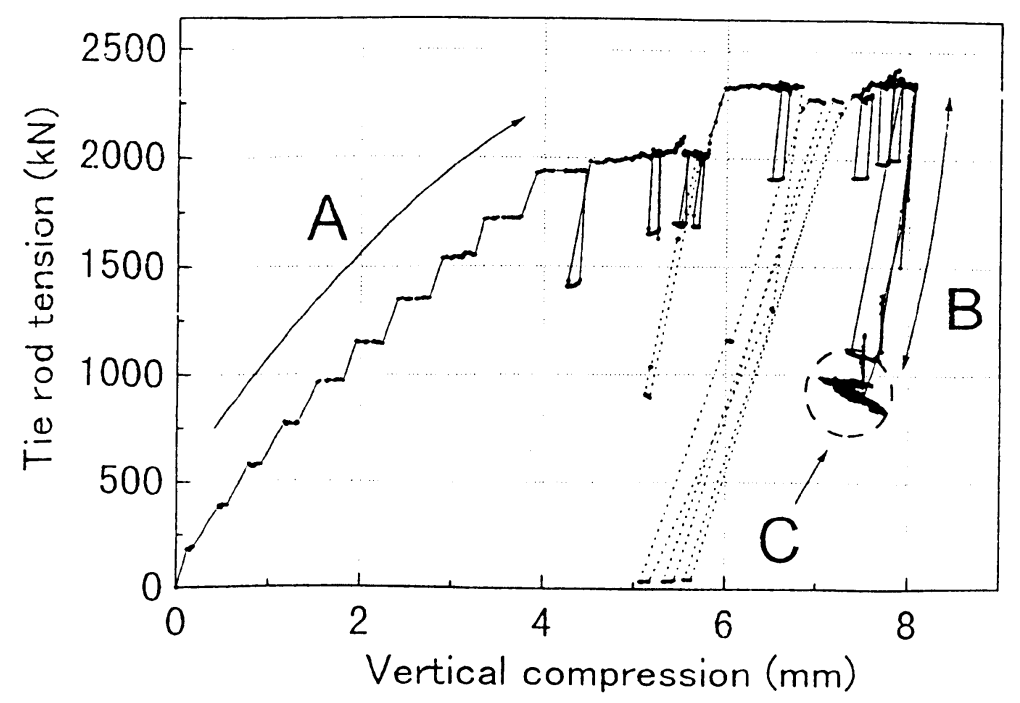

図 3 プレロード（タイ ロッド張力）と、盛土の 圧縮量の関倸

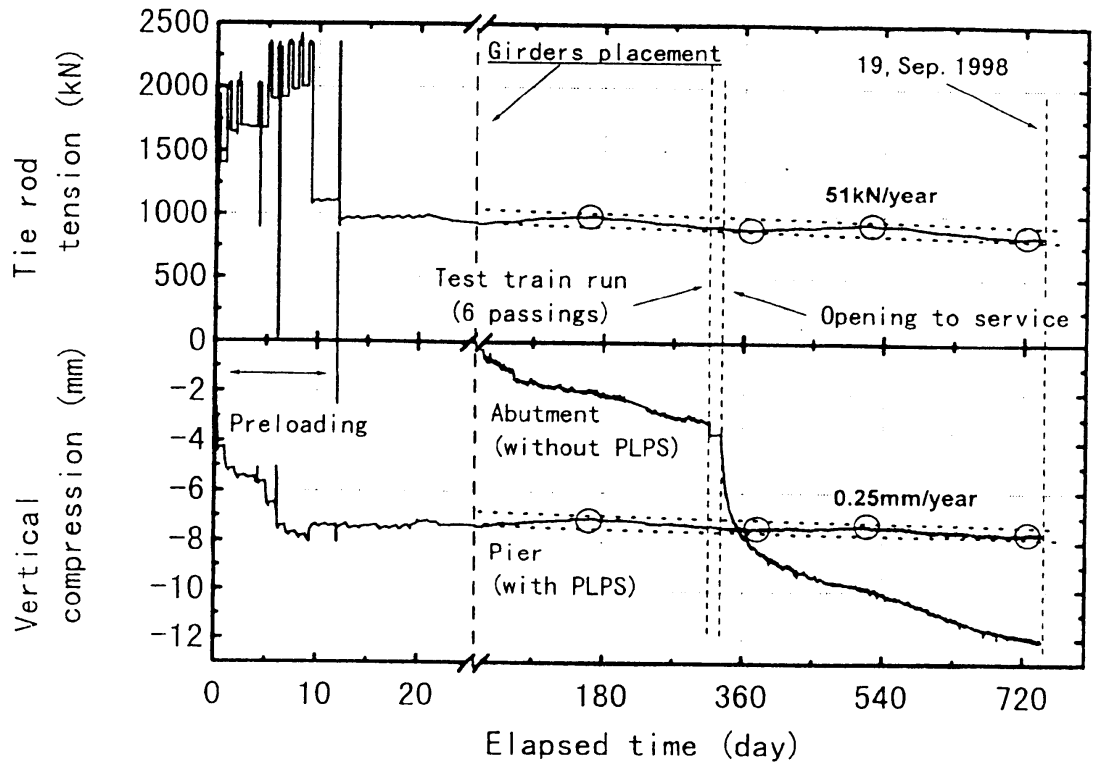

図4タイロッド張力お

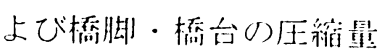
の経时䇣化

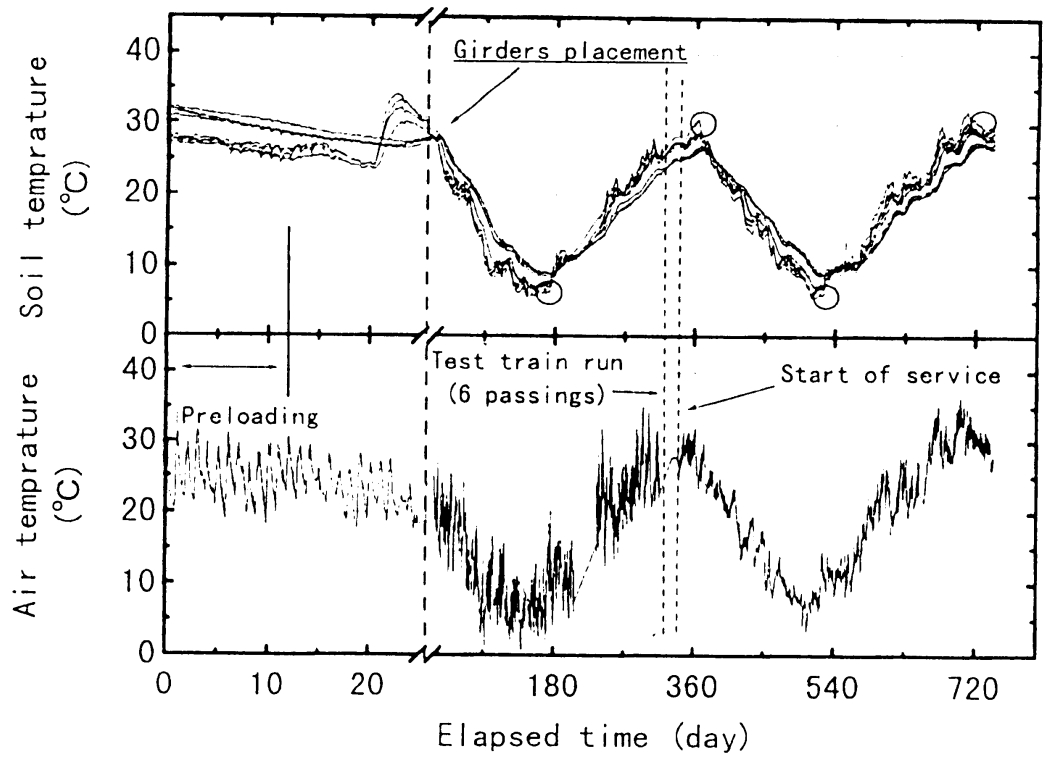

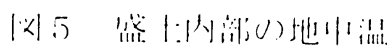

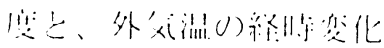


$\mathrm{P} \mathrm{L} \cdot \mathrm{P} \mathrm{S}$ 橋脚の圧縮率は十分小さく、5 年程度の仮設供用期間では問題にならないだろう。また、 タイロッドの張力は初期值 $950 \mathrm{kN}$ に対して約 $5 \%$ /年で减少しているが、これも 5 年程度なら問題にな らないだろう。但し、タイロッド張力が減少すると、盛土の㴊性が低下し4)う、列車荷重の繰返し載荷 による残留沈下が大きく生じるようになり、このためにタイロッド張力が減少するという悪循環に皕 る可能性があるので、さらに長期間供用するためにはタイロッド張力を維持する工夫が必要である。 具体的にはタイロッドの締結部にバネを挟んで、タイロッドのバネ定数を下げることが効果的だろう。

一力、P L・P S をかけていない補強土橋台は、桁を仮設したあとの圧縮量しか計測していないが、 供用開始までの約 9 ヶ月間に $3 \mathrm{~mm}$ 圧縮し、さらに供用開始後は急激に圧縮して、約 2 年間の総圧縮量 は $12 \mathrm{~mm}$ に達している。現在も圧縮が進んでいる。

図 6 は、盛土底面で測定した鉛直土圧で、P01は盛土中央部、P02は盛土端部のタイロッド付近で計 測したものである。これらの值も、温度変化による年周期変動が、顕著に現れている。媣さ $1 \mathrm{~m}$ 地 盤改良された領域を作って下部反力板に替わりとしているので、これが十分な剛性を持っていること が重要である。プレロード時の土圧の增加量は盛土の中央部もタイロッド付近も、ほぼ同じであるの

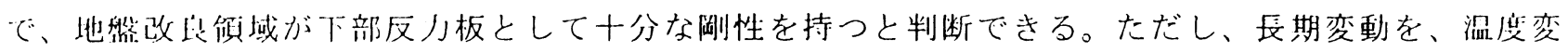
化による変動を除いて読みとると、中央部が $8.4 \mathrm{kPa} /$ 年で減少しているのに対して、タイロッド付近 は $4.0 \mathrm{kPa} /$ 年しか減少していない。従って長期的にはタイロッド付近に応力集中している。これは、 地盤改良された領域がクリープ変形して、中央部が下にたわんでいるか、あるいは R C 剛壁面に応力 が集中している可能性がある。

図 7 は、補強材の伸びひずみの変化を、補強材に貼ったひずみゲージで計測したものである。この ひずみゲージは、線路方向（橋脚の短辺方向）と線路直交方法（長辺方向）の伸びひずみを別々に測 るために、温度補償のとれない方法で㙋られている。すなわち、ブリッジを梇成する4枚のゲージの うち、アクティブゲージ 2 枚を伸びひずみを測る方向のストランド上に貼り、ダミーゲージ 2 枚はひ ずまないように威性の高い銅板に貼りつけて埋め込んだ。従って、2方向のひずみを別々に测ること ができるが、グリッドと銅板との熱膨張保数の差により、温度の影響が讨ている。

各方向に16点才゙つ、合計32点にゲージを貼って計测した。図 7 に、谷方向ごとの伸びひずみの平均 を示才。長期变動苍、温度变化による贺動を除いて読みとると、線路少向（留上の短边方向）にはほ とんど件びていないのに対して、線路泊艾方向（骎辽方问）には $0.0157 \%$ 柋 で補强材が件びている。

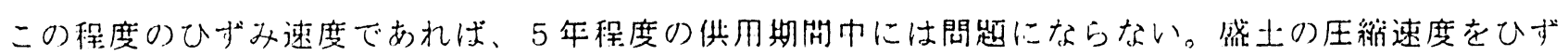

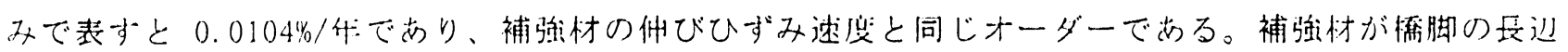
方向により大きく洲びている理用は分からない。

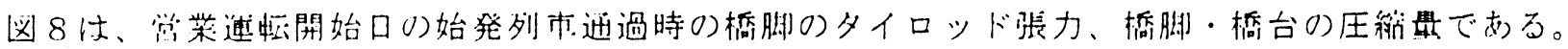

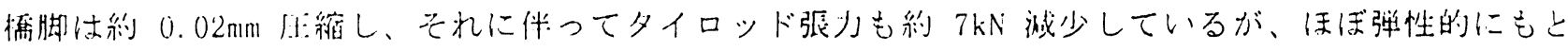

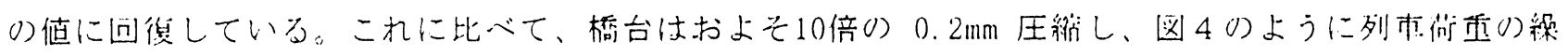

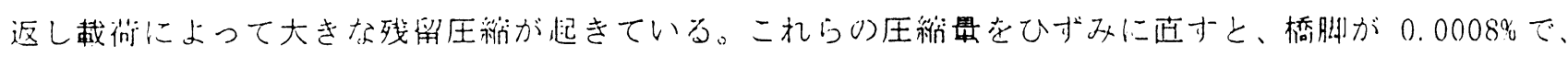

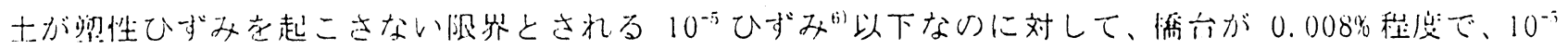

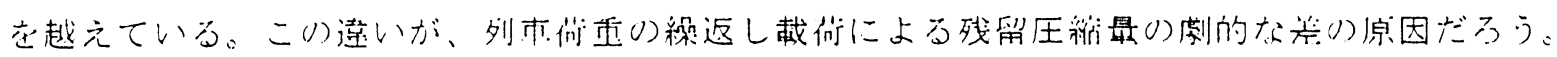



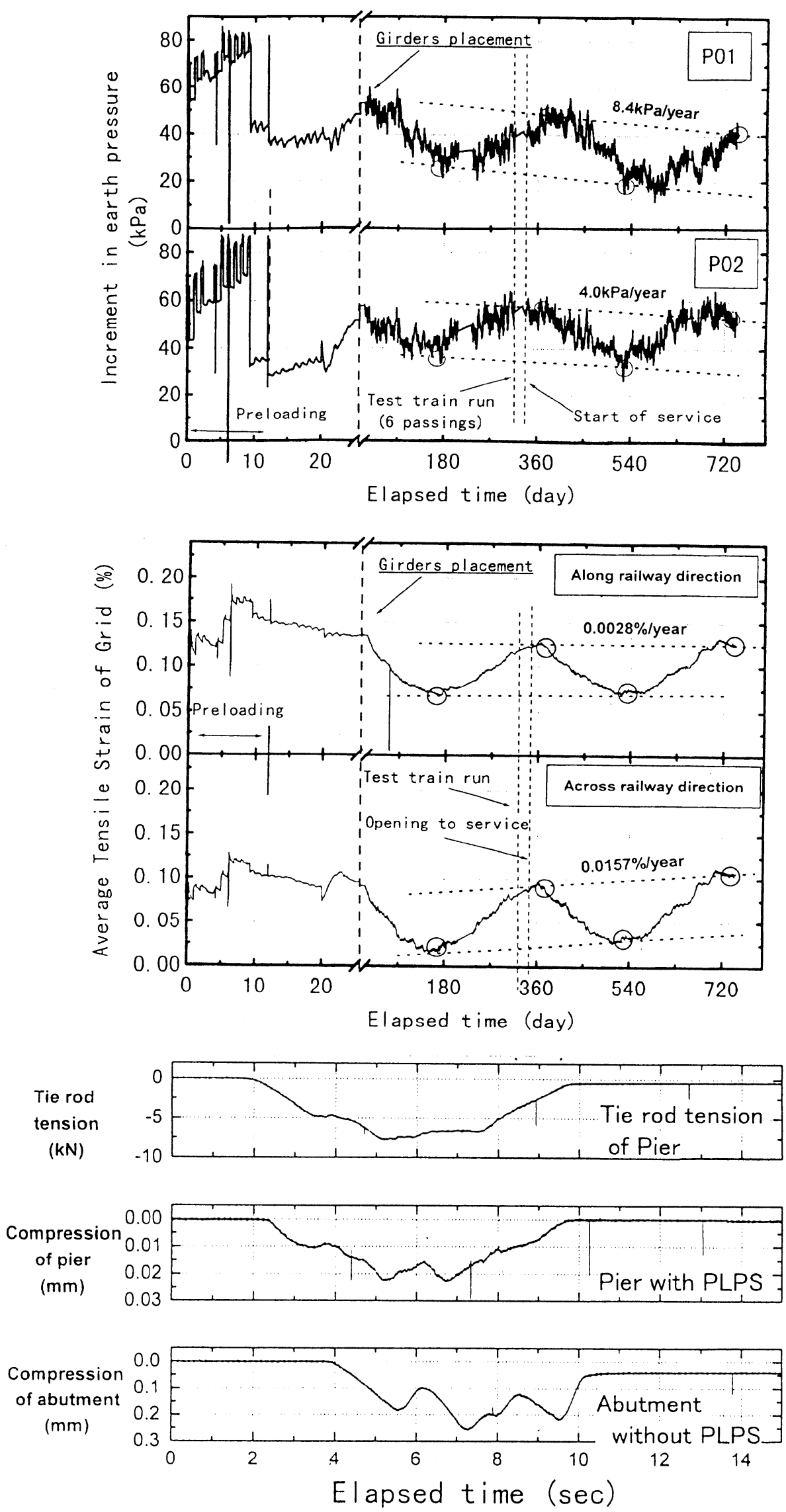

図6 P L - P S 橋脚心 盛土底部の土圧の経時恋 化

図 $7 \mathrm{PL} \cdot \mathrm{PS}$ 槅脚U) 補强材伸びひ子゙无U)経时 变化

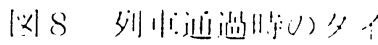

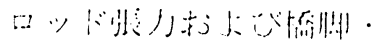

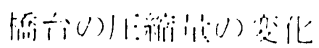


以上、長期および列車走行時の計測結果から考察した結論をまとめると、以下のようになる。

·P L・P S 橋脚は、死荷重によるクリープ圧縮速度、列車荷重の繰返し載荷による残留圧縮速度と も、実用上十分小さい。また、補強材の伸びひずみ速度も、十分に小さい。

・列車通過時、P L ・ P S 橋脚の圧縮量は十分小さく $10^{-5}$ ひずみを越えず、弾性的に挙動した。

・一方、P L ・ P S をかけない橋台は、列車通過時に $10^{-4}$ 程度圧縮し、急激に残留圧縮が累積した。

・タイロッド張力は、ゆっくりと減少しているが、 5 年程度では問題ないと思われる。

・基礎地盤を地盤改良して形成した下部反力板は、十分な剛性を持ち、反力板として機能している。

\section{P L ・ P S 補強盛土の設計・施工上の工夫}

上述の P L ・P S 補強盛土の実施工や、筆者らが過去に行ってきた実物大模型の実験から、P L ・ P S 補強土工法の設計・施工上、工夫すべき点として、次のことが考えられる。

3. 1 P L · P S 補強盛土の圧繀性

本工法の第一の目的は、補強盛土の鉛直方向の圧縮を抑制することである。圧縮の要因は、(1)供用 荷重の繰返し載荷による残留圧縮、(2)供用荷重による一時的な圧縮、(3)自重や静的荷重による長期的 なクリープ圧縮である。このうち、繰返し荷重による残留圧縮については、上述の実施工の橋脚と橋 台の比較から、供用荷重载荷時の一時的な圧縮ひずみを.10-5以下に抑えればよい。また、これを満た せば、一時的な圧縮の最大許容值も、自動的に満たせるだろう。従って、定量的な締固め管理と、プ

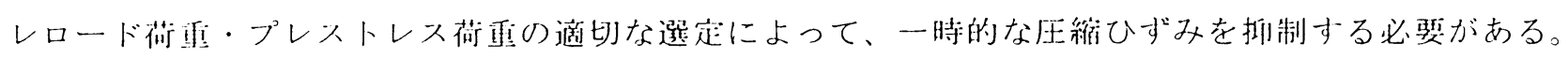
特に盛士の㴊性を支配寸るのは、プレストレス荷重であるからり、これと、平板载荷試験などによっ て得られる盛土の初期の岡性とから、盛土の一時的な圧縮ひずみを予測することになるだろう。

3. 2 プレロードの载待方法

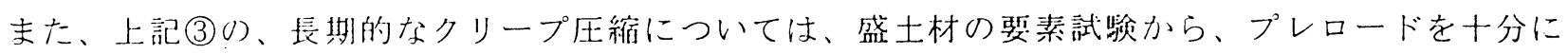
かけてから除荷与る踏によって、效果的に抑制されることが分かっているいう。プレロードを一時的に

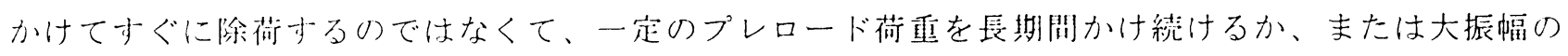
綝这し荷重をかけることで、盛士を十分に压維与ることが效果的である。特に緥返し荷重によるプレ

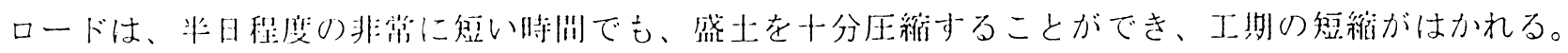

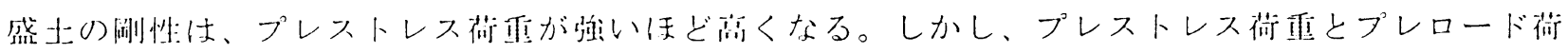

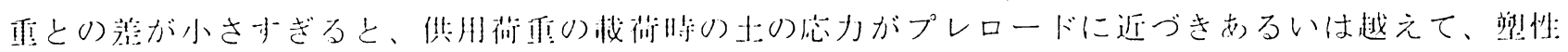

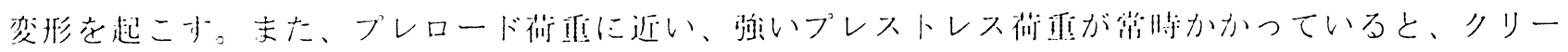

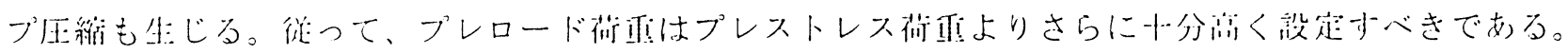
3. 3 タイロッド找力ひ維拈

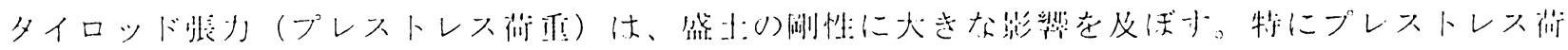

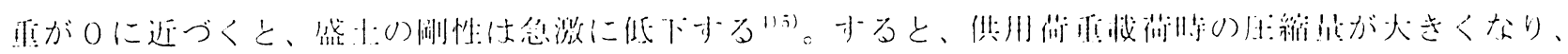

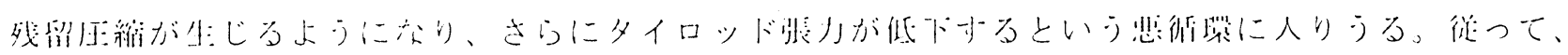

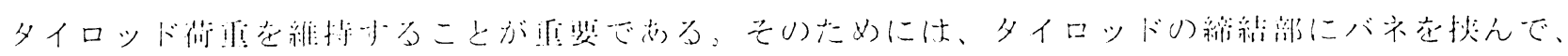




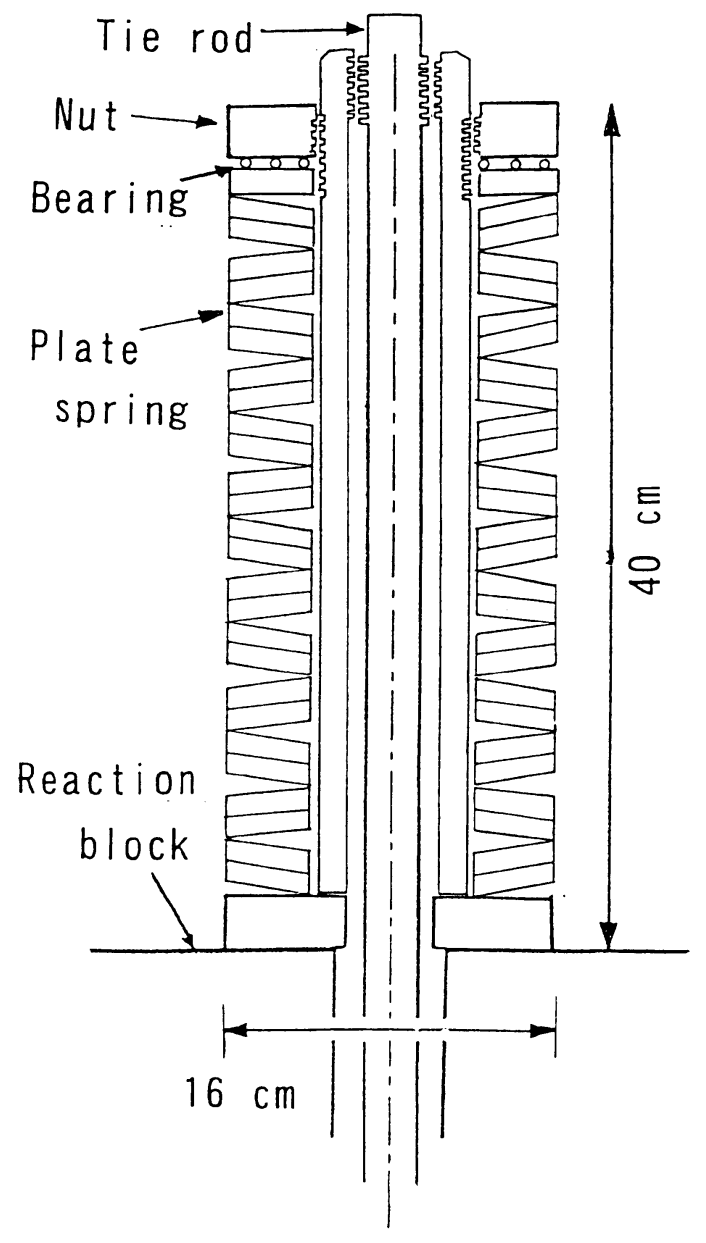

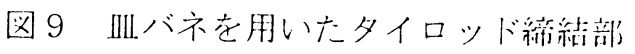

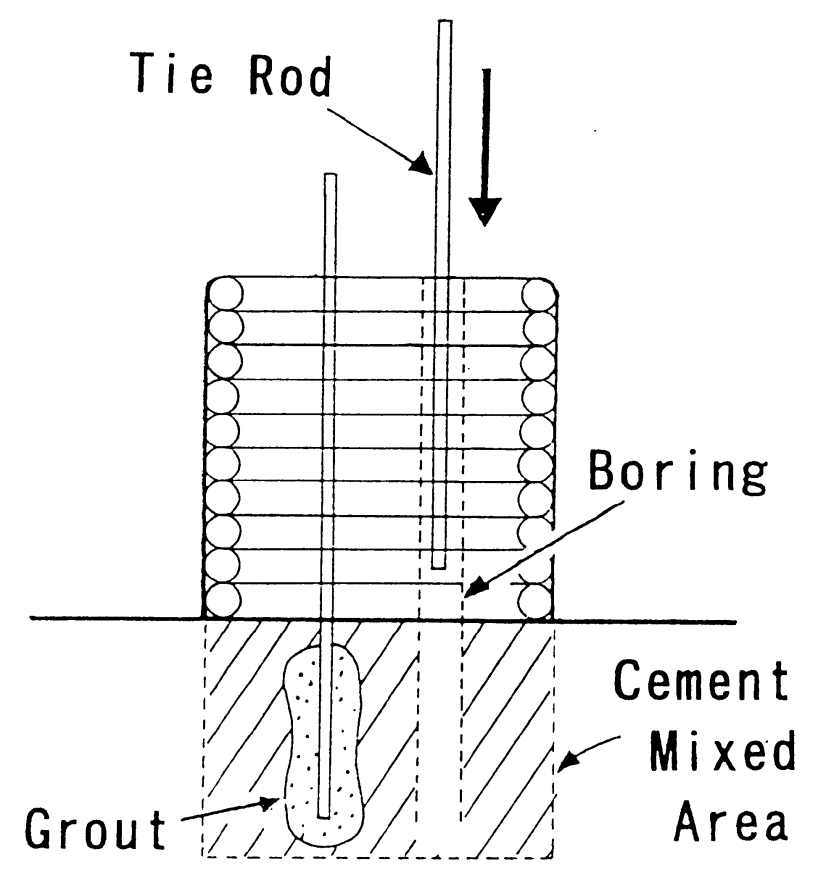

タイロッドのバネ定数を下げることが効果 的だろう。筆者らは、具バネを用いたタイ ロッド締結部を試作している（図9）。夕 イロッドー本につき、直径 $16 \mathrm{~cm}$ の皿バネ を 26 枚を用い、30tf の張力を支える。上 述の実施工のP L ・ P S 橋脚にこれを用い れば、タイロッドのバネ定数が約 1/10に なり、張力の減少速度を $1 / 10$ に減らせる。

\section{4 タイロッドの設置方法}

上述の実施工 P L P S 橋脚では、初め にタイロッドを設置してから盛土を構築し たので、タイロッドの間を縫うように作業 することになり、施工性が悪かった。改善 案として、基礎地盤を地盤改良することで 下部反力板を作り、タイロッドを設置せず に盛土を構築し、最後に天端から改良した 基礎地盤まで削孔してタイロッドを捅入し て定着する方法が考えられる（図１０）。 タイロッドの插入と定着は、技術的にはグ ラウンドアンカーなどですでに行われてい る。また、上述の橋脚の事例から、地盤改 良によって形成した下部反力板で主、十分 な剛性を持っことが確かめられている。

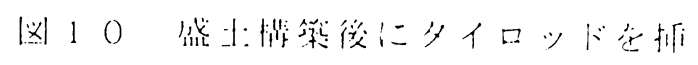

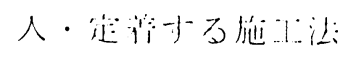




\section{4.まとめ}

実施IUPL・P S 補強土橋脚の長期挙動と列車走行時の挙動を計測した結果、P L P P S 補強盛 土は、実用上十分な崳性を持ち、また長期にわたって変形が小さく姵性が維持されることが分かった。 また、P L・P S 補強盛土の剛性を長期にわたって維持することと、施工性の改善の観点から、設計・ 施工上工夫すべき点を考察した。

\section{5. 謝辞}

実施工の P L ・ P S 補強土橋脚の構築・計測にあたり、鉄道総合技術研究所の小島謙一氏、木村英 樹氏、九州旅客鉄道株式会社の前田崇氏、鶴英樹氏、高山智宏氏、東京大学生産技術研究所の任藤剛

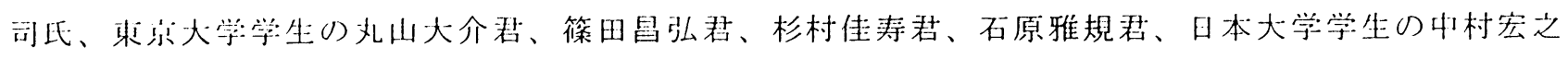
若に、多大な協力を戴きました。媣く感謝いたします。

\section{参考文献}

1) Uchimura, T., Tatsuoka, F., Sato, T., Tateyama, M. and Tamura, Y. 1996. Performance of preloaded and prestressed geosynthetic-reinforced soil, Proc. Int. Symp. on Earth Reinforcement, Fukuoka, Balkema (Ochiai et al., eds), Vol. 1, pp. 537-542.

2）内村太郎·龍岡文夫·館山勝・古関潤一・前田崇·鶴英樹(1996)：プレローディド・プレストレスト補 強盛土のメカニズム・原理実験・実大模型実験・実施工, 第 11 回ジオセンセティックスシンポジウム 発表論文集, 国際ジオセンセティックス学会日本支部, pp. 72-81

3) Uchimura, T., Tatsuoka,F., Tateyama, M., Koga, T. 1998: Preloaded-Prestressed Geogridreinforced Soil Bridge Pier, Proc. the 6th Int. Conf. on Geosynthetics, Atlanta, Vol.2, pp. $565-572$.

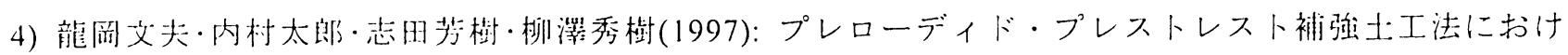
るプレストレスの效果,第32回地盤工学研究発裴会発表誹演集,pp2475-2476

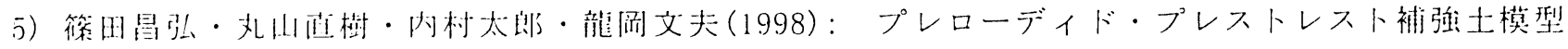

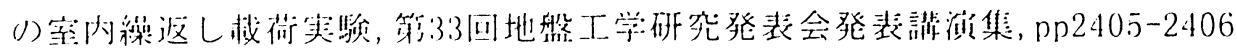

6) Kohata, Y., Tatsuoka, F., Dong, J., Teachavorasinskun, S. and Hizumoto, K. (1994), "Stress states affecting elastic deformation moduli of geomaterials, "Proc. of Int. Symp. on Pre-Failure Deformation of (ieomaterials (Shibuya et al., eds.), Balkema, Vol.1, pp.3-9 